\title{
Poéticas do desejo e dos prazeres LGBTQ na Poesia gay brasileira
}

\author{
Poetics of Desire and LGBTQ Pleasures in Poesia gay brasileira \\ Poéticas del deseo y de los placeres LGBTQ en Poesia gay brasileira \\ Claudicélio Rodrigues da Silva*
}

\begin{abstract}
Resumo
Antologia é um compêndio de textos, de um ou vários autores, escolhidos por um organizador com a finalidade de colocar em evidência uma estética, um período ou uma temática. Antologias, portanto, dizem muito das políticas editoriais e sociais do seu tempo. Desse modo, o artigo se propõe a analisar Poesia gay brasileira (2017), coletânea que reúne poemas do século XIX ao XXI a partir da temática da homossexualidade ou homoafetividade. O recorte do estudo, porém, se restringe aos textos nos quais o discurso encena os afetos LGBTQ, o desejo e suas tensões, os prazeres e suas marcas na cultura. Em suma, interessa pensar como o discurso sobre as práticas eróticas desses sujeitos se desloca para uma postura política sobre a sexualidade. Entre outros suportes teóricos, a análise baseia-se em Butler (2017; 2019a; 2019b), Foucault (2015), Preciado (2011; 2014), Rolnik (2018), Rubin (2017), Sejo e Carrascosa (2016) e Vidarte (2019).
\end{abstract}

Palavras-chave: homoafetividade, antologia, poesia gay brasileira, sujeitos dissidentes.

\section{Abstract}

An anthology is a compendium of texts, from one or many authors, chosen by an organizer to draw attetion to an aesthetic, time or topic. Anthologies, thus, say a lot about the editorial and social politics of the time in which it appears. Therefore, this article aims to analyze Poesia gay brasileira (2017), a collection of poems from the XIX to XXI centuries about homossexuality or homoaffectivity. This study, however, examines texts which stage LGBTQ affection, desire and its tensions, pleasure and its cultural presence. Essentially, it's interesting to think how the discourses around LGBTQ's erotic practices puts these subjects in a political position with regard to their sexuality. Among other theorical supports, this analysis is grounded in works by Butler (2017; 2019a; 2019b), Foucault (2015), Preciado (2011; 2014), Rolnik (2018), Rubin (2017), Sejo and Carrascosa (2016) and Vidarte (2019).

Keywords: homoaffectivity, anthology, brazilian gay poetry, dissident subjects.

\section{Resumen}

Una antología es un compendio de textos, de uno o varios autores, elegidos por un organizador con la finalidad de poner en evidencia una estética, un período o una temática. Antologías, por lo tanto, dicen mucho de las políticas editoriales y sociales de su tiempo. De ese modo, el artículo propone la investigación de Poesia gay brasileira (2017), colección que reúne poemas de los siglos XIX al XXI a partir de la temática de la homosexualidad o homoafectividad. El recorte del análisis, sin embargo, se restringe a los textos en los que el discurso escenifica los afectos LGBTQ, el deseo y sus tensiones, los placeres y sus marcas en la cultura. En suma, interesa pensar como el discurso sobre las prácticas eróticas de esos sujetos se desplaza hacia una postura política sobre la sexualidad. Entre otros soportes teóricos, el análisis se basa en Butler (2017; 2019a; 2019b), Foucault (2015), Preciado (2011; 2014), Rolnik (2018), Rubin (2017), Sejo y Carrascosa (2016) y Vidarte (2019).

Palabras-clave: homo-afectividad, antología, poesía gay brasileña, sujetos disidentes.

\footnotetext{
*Universidade Federal do Ceará (UFC), Fortaleza, CE, Brasil. (Dorcid.org/0000-0003-4879-9416. E-mail: claudicelio@ufc.br
} 


\section{Sobre políticas do desejo}

A história da sexualidade revela como os homens orientaram e continuam orientando seus interesses políticos e econômicos por meio de relacionamentos amorosos, culminando em disputas nas quais o que estava e está em jogo é o poder. Sexo é poder e é político; o desejo e o prazer também. Entretanto, a quem interessa o discurso hegemônico que a humanidade construiu sobre a sexualidade? Interessa a quem uma sociedade cuja estrutura se fundamenta no binarismo não horizontal masculino/feminino, público/privado, ativo/passivo, dominador/dominado?

O que fazemos com o desejo e os prazeres não é, como costuma aventar a filosofia do senso comum e dos moralistas, meramente de foro íntimo. Pelo contrário, o desejo sempre foi um objeto a ser compreendido pelas esferas de poder, sejam elas a Igreja, o sistema econômico, os órgãos jurídicos ou o Estado. Na História da sexualidade 1, Foucault (2015) fala de uma incitação aos discursos sobre o sexo no Ocidente, especialmente durante a modernidade. Por meio da confissão sacramental, médica e psicológica, ou ainda, por meio dos tribunais de justiça, os sujeitos eram estimulados a confessarem-se corpos desejantes, a assumirem o desejo como culpa secular, como desajuste social ou como patologia.

Considerando o que afirma a estudiosa e ativista lésbica americana Gayle Rubin em "Pensando o sexo: notas para uma teoria radical da política da sexualidade", um dos textos seminais da teoria queer, as questões referentes às artimanhas de Eros "muitas vezes se tornam um veículo para deslocar angústias sociais e descarregar as intensidades emocionais concomitantes a elas". Portanto, as ações de Eros ligam-se necessariamente a uma política, uma vez que "o domínio da sexualidade também tem uma política interna, desigualdades e modos de opressão próprios" (Rubin, 2017, p. 6364). Rubin enfatiza que a sexualidade é uma construção complexa, que abarca o biológico, o social e o cultural. ${ }^{1}$ Por isso, o desejo e seus dispositivos são tão vigiados em qualquer sociedade, independentemente do regime político e econômico em que esteja ela assentada.

Rubin alerta para a negatividade que se assenta sobre tudo o que diz respeito ao sexo, "considerado culpado até que se prove sua inocência. Praticamente todos os comportamentos eróticos são considerados maus a menos que se estabeleça uma razão específica para isentá-los" (Rubin, 2017, p. 82). Segundo a teórica, o erótico ficaria isento de condenação nos seguintes casos: na maior parte, quando estiver a serviço do casamento, da reprodução e do amor; e em menor grau, ao servir de objeto de investigação científica ou estética. Normativa ou não, a sexualidade é constantemente vigiada, recebendo, inclusive, uma escala de aceitação, denominada por Rubin de "estratificação sexual" dos sujeitos eróticos, ou seja, o que é mais ou menos aceitável dentro do espectro de orientações sexuais. Isso se assemelha ao pensamento de Judith Butler (2019a), segundo a qual todos os sujeitos performam em matéria de gênero, a diferença estaria justamente em quem acerta ou falha nessa atuação segundo os paradigmas da sociedade.

Escrito em 1982, o texto de Rubin chamava a atenção para o modo como a sociedade moderna capitalista estrutura os comportamentos dos sujeitos a partir do que se espera deles em matéria de desejo. Somos agenciados para colocar o desejo a serviço de tudo, menos do prazer pelo prazer. Resumindo: somos cafetinados pelo Estado. É sobre isso o livro Esfera da insurreição, de Suely Rolnik, que analisa como o "inconsciente colonial-capitalístico ou colonial-cafetinístico" pode exercer uma "sedução perversa sobre o desejo cada vez mais violenta e refinadamente, levando-o a se entregar ainda mais gozosamente ao abuso" (2018, p. 25). Obviamente, toda a ação do capitalismo estará sempre procurando agenciar e direcionar o desejo dos que estão a seu serviço. A essa obsessão a autora chama de cafetinagem, e seu texto se coloca num percurso investigativo cujo objetivo é encontrar estratégias para se recusar a cafetinagem de nossa pulsão vital. Rolnik encontra exemplos

\footnotetext{
${ }^{1}$ Paul B. Preciado (2011, p. 11) denomina de "sexopolítica" uma das muitas formas de poder no capitalismo contemporâneo, que coloca sob o seu domínio as práticas sexuais, as identidades normais e desviantes, os códigos de masculinidade e feminilidade. Não à toa, Monique Wittig, em famoso texto de 1978 intitulado O pensamento heterossexual, citada por Preciado nesse artigo, assegura que a heterossexualidade é menos uma prática sexual do que uma categoria política. Judith Butler (2019b, p. 15), ao pensar sobre a materialidade do corpo, assegura que o sexo "não só funciona como norma, mas também é parte de uma prática regulatória que produz os corpos que governa, ou seja, cuja força regulatória é evidenciada como um tipo de poder produtivo, um poder de produzir - demarcar, circular, diferenciar - só corpos que controla".
} 
de deslocamentos nos estudos culturais, pós-coloniais, queer, mas também cita ressonâncias de uma luta coletiva contra a cafetinagem na canção popular, na sexualidade e até nos discursos dos povos indígenas que ultrapassam a geografia das aldeias $(2018$, p. 38). Não à toa, essas potências criadoras são os primeiros alvos de antipolíticas das forças neoliberais e conservadoras, porque, como afirma Paul B. Preciado, no prólogo do livro de Rolnik, "encarnam no imaginário conservador a possibilidade de uma autêntica transformação micropolítica" (2018, p. 13).

Rolnik propõe um "exercício de fabulação" a partir da obra "Caminhando", de 1963, de Lygia Clark, que consiste em inserir cortes numa fita de Moebius nunca fazendo incisão no ponto de início, até que não haja mais possibilidade de corte. A fita representaria a "superfície topológico-relacional do mundo" e o corte, as tentativas de desestabilizar os parâmetros instituídos. Assim, diante do que se coloca como forma paradigmática da vida, duas políticas do desejo, situadas em polos opostos, impõem ao sujeito uma ação. O sujeito que escolhe a "micropolítica ativa de bússola ética" saberá aproveitar o estranhamento e a instabilidade, enquanto quem escolher a "micropolítica reativa", cuja bússola é a moral, não sabendo conviver e tirar proveito da desestabilização, reagirá no intuito de anular a tensão. Rolnik alerta que essa última micropolítica coloca o desejo como subserviente do inconsciente colonial-capitalístico. Quando a subjetividade se depara com o inabitual, é o desejo que provoca essa tensão, e a saída é fazer cisões, cortes e desvios: "Nessa micropolítica, as ações do desejo consistem portanto em atos de criação que se inscrevem nos territórios existenciais estabelecidos e suas respectivas cartografias, rompendo a cena pacata do instituído" (Rolnik, 2018, p. 61).

Pensando na literatura como um desses territórios que devem ser tensionados e cindidos para que se rompa "a cena pacata do instituído", como quer Rolnik, a hipótese aqui posta é a de que os contradiscursos dos sujeitos minoritários e dissidentes, antes objetos do discurso literário, mas que agora assumem um lugar de fala, desnorteiam a natureza acostumada e historicamente inabalável do cânone. Mulheres, gays, lésbicas, negros e índios são personas retratadas na literatura brasileira desde a Colônia, sem, no entanto, quase nunca poderem se autorrepresentar para elaborar suas próprias formas de se colocar no mundo através do literário.

Por entender que a política é um produto social sempre movente, que arregimenta os corpos sociais - quer na esfera pública, quer no âmbito do privado - na direção de certo tipo de atuação, e que os múltiplos discursos de poder colidem, compreendo que a literatura pode ser um mecanismo a partir do qual os corpos desejantes se autoafirmem. Portanto, interesso-me aqui pelo Eros dos sujeitos dissidentes e seus discursos na literatura. Como recorte, meu objeto de estudo são as antologias que reúnem textos ficcionais ou poéticos a partir da temática do erotismo pela perspectiva das minorias. No caso específico deste artigo, analiso a antologia Poesia gay brasileira (2017). Além disso, embora leve em consideração o conjunto dos temas e configurações discursivas da antologia, devo apenas me debruçar sobre os textos que encenem o desejo e os afetos eróticos.

\section{Poéticas do desejo LGBTQ: uma micropolítica}

É possível falar de uma política do corpo LGBTQ e de sua representação na poesia brasileira atual a partir do que Rolnik denomina de "micropolítica ativa de bússola ética"? Como a sexualidade está sendo encenada no discurso literário atual? De que marcas estéticas a linguagem poética se reveste para falar dos afetos lésbico, gay, bi, trans e queer? Na verdade, essas questões fazem parte de outras mais abrangentes feitas por Denilson Lopes em "Uma história brasileira", de $O$ homem que amava rapazes: "O que um olhar homoerótico acrescenta à cultura brasileira e como a representação da homossexualidade se torna ou não estrutural a sua literatura?" (2002, p. 121). O pesquisador traça um panorama da história da "homotextualidade" no Brasil, assim como já havia ensaiado João Silvério Trevisan em Devassos no Paraíso (2018), cuja primeira edição é de 1986. Mapear e historicizar esses textos é uma tarefa incipiente, mas promissora, especificamente porque o século XXI e suas vozes militantes LGBTQ, dentro e fora do espaço literário, têm procurado elaborar uma crítica, uma teoria e uma historiografia sobre a representação de si na cultura. 
Os sujeitos minoritários anseiam por políticas do desejo que não se submetam a discursos e ações compulsórias. E isso tem acontecido, quer nas ações políticas das militâncias, quer nas atuações de produção de pensamento, quer ainda na produção poética. Ao menos desde que as militantes lésbicas (negras ou não) das décadas finais do século XX começaram a tensionar o feminismo diante da necessária pluralidade de lutas (a mulher negra, a mulher pobre, a mulher lésbica, a mulher prostituta, a mulher operária etc.), o que vimos foi a irrupção de teorias que, a partir de sua perspectiva de mundo quanto à sexualidade e sua identidade de gênero, começaram a propor tensionamentos, a fazer cortes no tecido da "superfície topológico-relacional do mundo", para usar o termo de Rolnik. A pluralização do feminismo a partir dos anos 1980 (segunda onda), a leitura e produção crítica de gays e mulheres lésbicas e negras nos anos 1990 (terceira onda), e a tensão entre feministas antipornografia versus feministas pró-sexo, culminam na elaboração das teorias queer e na radicalização da negação do binarismo de gênero. ${ }^{2}$

Pensemos nos corpos eróticos como potências políticas que, ao mesmo tempo que encenam modos de desejar e de realizar o desejo também questionam o modo como vêm sendo expostos ao erotismo dos outros. Gayle Rubin, ao afirmar a natureza política do sexo, alerta para momentos históricos em que os domínios da sexualidade se tornam mais politizadas e "o domínio da vida erótica é com efeito renegociado" (2017, p. 64). Ora, se o domínio do prazer e do desejo é ainda um território do masculino, é preciso retirar o erotismo dessa instância e representá-lo sob as múltiplas perspectivas das figurações de gênero. Quanto mais houver ameaças às comunidades eróticas desviantes do sonho de uma sociedade, ${ }^{3}$ mais os sujeitos afetados por táticas para incitar a histeria erótica devem elaborar contradiscursos à altura dos ataques nos quais se denunciem a heterodiscursividade de hegemonia masculina, e até mesmo o discurso antissexo e a retórica antipornográfica que Rubin já questionava também dentro do feminismo na década de 1980.

Ao discorrer sobre os dispositivos da sexualidade, Foucault dizia que "entre seus emblemas, nossa sociedade carrega o do sexo que fala. Do sexo que pode ser surpreendido e interrogado e que, contraído e volúvel ao mesmo tempo, responde ininterruptamente" (2015, p. 85). Ao me propor a pensar o corpo político de Eros nos corpos dissidentes, levanto a hipótese de que, na literatura erótica escrita atualmente, o espaço privado da cama, território da intimidade e do prazer, é também o território do discurso crítico, revisionista e subversivo quando se torna representação ficcional e poética. ${ }^{4} \mathrm{~A}$ encenação do corpo que deseja, que realiza o desejo com o outro ou sozinho, pode ser entendida como um ato performativo, na acepção de Judith Butler (2017), ao propor que a ideia de gênero é performativa e que nos construímos como homem ou mulher por meio da repetição de atos que dependem de convenções sociais. Assim, os sujeitos dos poemas de temática LGBTQ, enquanto se tocam ou são tocados, pensam ou são pensados como enunciadores do discurso erótico. Trata-se de uma via de mão dupla: aquele que deseja, também racionaliza o ato de desejar enquanto poetiza, assim como aquele que fode, também poetiza o ato de foder racionalizando.

\section{Antologizando a dissidência}

A palavra dissidência tem sido utilizada no lugar de minorias para inserir no debate a perspectiva dos que assumem o contradiscurso como força operante de suas vidas. $O$ dissidente é o sujeito subversivo por excelência, que constrói para si percursos outros, bem destoantes dos hegemônicos. Ele não apenas dribla normas e territórios minados por

\footnotetext{
${ }^{2}$ Gayle Rubin, Monique Wittig, Audre Lorde, Judith Butler, Eve Sedwik, Andreia de Lauretis e, mais recentemente, Paul B. Preciado, entre outrxs, formam o núcleo de ativistxs-pensadorxs, produtorxs de poéticas e de políticas que compreendem saberes novos sobre os sujeitos antes vistos como aberração e desvios. Não à toa, a sigla GLBT foi alterada para LGBT como forma de demarcar a contribuição das lésbicas para a discussão e crítica das lutas quer do feminismo, quer dos sujeitos queer.

${ }^{3}$ Rubin relata como as repressões sexuais de três décadas (1850, 1950 e 1970) nos Estados Unidos da América colocaram como alvo a prostituta e o homossexual. As condutas desses sujeitos passavam a ser designadas por leis. Para isso, a sociedade era incitada a aderir ao discurso condenatório através de campanhas de amedrontamento. Nesses momentos, surgem sempre os discursos em favor da proteção da família, das crianças e do sagrado.

${ }^{4} \mathrm{Na}$ verdade, a literatura é um território onde o sexo sempre foi uma obsessão. Entretanto, mais que saber disso, é preciso fazer uma arqueologia dos discursos do sexo na literatura: a serviço de quem ele falava? Sobre o que falava? Que prazer encenava?
} 
estruturas excludentes, como traz para si a responsabilidade de atravessá-las, ocupando-as e produzindo objetos em que se possa ver. ${ }^{5}$ As palavras que orbitam o vocábulo "dissidência" podem ajudar a compreendê-lo, mas sem delimitá-lo: oposição, subversão, transgressão, objeção, desobediência, ruptura. Resumindo, não se trata apenas das práticas discursivas de um sujeito insurgente, mas da construção de saberes sob as perspectivas dos atravessamentos e das interseccionalidades. Gayle Rubin (2017) chama de "dissidentes eróticos e sexuais" os estigmatizados por causa de sua orientação sexual: são expulsos da família, do mercado de trabalho, da vida social. Judith Butler $(2018$, p. 39) se utiliza da palavra para discutir a negociação que os sujeitos fazem com o poder para representar um gênero. Ao falar sobre a "interpelação de gênero" dos que rompem com a normalidade, a pensadora destaca como "modos hiperbólicos ou dissidentes de masculinidade e feminilidade" todos os que recusam a categorização e normas de gênero. ${ }^{6}$

Considerada pelas organizadoras como a primeira antologia de poesia gay no Brasil ${ }^{7}$, Poesia gay brasileira: antologia (2017) reúne 127 poemas de 44 autores, representando um período que vai do século XIX ao presente, numa seleção que contempla românticos, modernistas, pósmodernistas e contemporâneos. Resguardando os diferentes contextos de produção, o que esses poetas, de épocas e com objetivos distintos, podem dizer sobre as políticas dissidentes? Especificamente, nos poemas publicados a partir da segunda metade do século XX, os temas apresentam um repertório variado de assuntos: denúncia à intolerância e homofobias, referências bíblicas sobre a criação do homem e sobre a homossexualidade com certas doses de rebaixamento do discurso religioso, paródias e prostituição masculina, práticas BDSM, virilidade, a pandemia da aids, o feminicídio, a homofobia e, é claro, os modos de ser e desejar de gays, lésbicas, travestis e transexuais.

Essa variedade temática demonstra quão complexas são as identidades que dinamitam o binarismo e, com ele, a hierarquia do masculino sobre o feminino. Os discursos dos afetos queer não podem ser colocados em segunda instância nem considerados menores em face das políticas que esses textos veiculam. A reunião de poemas sobre homossexualidade numa antologia evidencia o que Preciado reconhece como um contrato, ou seja, os sujeitos percebem a dialética dos corpos-falantes que "reconhecem em si mesmos a possibilidade de aceder a todas as práticas significantes, assim como a todas as posições de enunciação, enquanto sujeitos, que a história determinou como masculinas, femininas ou perversas" (2014, p. 21). De certo modo, os textos de antologias como a Poesia gay brasileira estão repletos de sujeitos que compreendem a dimensão política dos corpos e, afetados por uma história de opressão ao sexo e ao gênero, decidem abalar as representações compulsórias do desejo, assumindo seu lugar discursivo nos espaços que sempre os representaram, mas nunca os deixaram falar da política dos afetos a partir de suas vivências.

Embora considere um recorte inexpressivo da diversidade de vozes da antologia gay, a leitura que ensaio a partir de agora serve de ilustração da dupla abordagem do discurso sobre as práticas eróticas/políticas. Tais poemas representam bem a afirmação de que toda erótica, quando se torna discurso poético, é também uma ação política.

O poema a seguir, de Alessandra Safra, cujo tema é o afeto lésbico, apresenta uma duplicidade em relação à natureza erótica, ou seja, a ação da língua enquanto órgão do corpo físico no ato sexual também estabelece uma reflexão sobre a linguagem que enuncia o alfabeto do afeto entre duas mulheres:

\footnotetext{
${ }^{5}$ Penso aqui nas inúmeras produções estéticas da contemporaneidade que abordam os amores dissidentes no campo das artes visuais, do cinema, da fotografia, do teatro e da literatura. Essas produções político-estéticas têm sido denominadas de artivismo.

${ }^{6} \mathrm{O}$ texto de Butler trata da política de gênero e da condição precária dos sujeitos que, por se oporem ao instituído como normal, acabam se expondo e entrando nas estatísticas da vulnerabilidade.

${ }^{7}$ As organizadoras mencionam a antologia Poemas do amor maldito (1969), organizada por Gasparino Damata e Walmir Ayala, que tratou do amor entre iguais, mas insistem que os organizadores não demarcaram aqueles poemas como gays, apesar de tanto a orelha quanto o prefácio daquela antologia afirmarem isso.
} 
Ando no tempo da língua de alguém

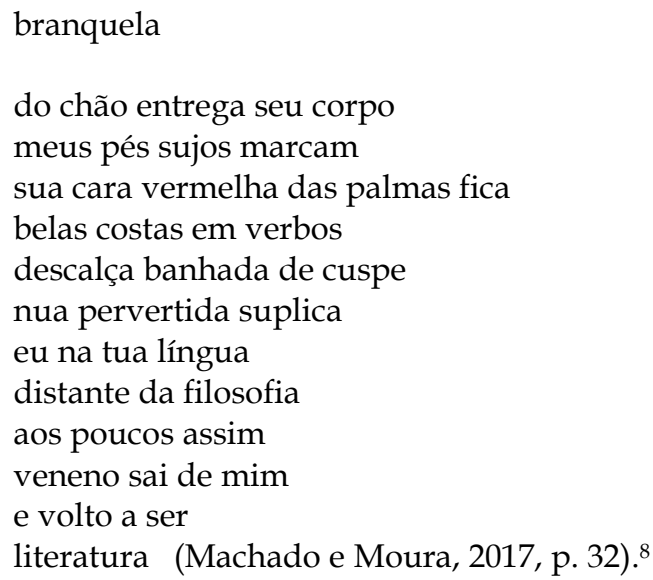

A descrição da intimidade dos corpos coloca em evidência não o órgão sexual, que sequer é mencionado, mas a língua que, junto com mãos e pés, compõe o alfabeto do enlace amoroso da linguagem lésbica. Erótica é a língua, que explora o corpo-poema ou o poema-corpo. Não se trata de mera descrição da intimidade lésbica, mas de mapear as configurações do desejo e do prazer numa experiência desviante, no sentido de não haver aqui qualquer possibilidade de valorizar o que a linguagem erótica normativizada pelo interesse do masculino sobre o feminino configurou como alfabeto do prazer. Além disso, o próprio poema brinca com a condição literária do jogo de cena, sugerindo que tudo não passa de uma construção, portanto, estamos no domínio do literário. Essa natureza desviante do erotismo e da poesia já foi estudada por Octavio Paz (1994), em A dupla chama, ao afirmar que o erotismo se desvia do sexo enquanto função reprodutora, e a poética se desvia da linguagem meramente comunicacional, culminando num jogo linguístico que vê o erótico na poesia e a poesia no erótico. Portanto, trata-se de um poema construído a partir da metalinguagem sobre o ser do erótico e o ser do poético.

Também construído de metalinguagem, o poema de Francisco Bittencourt, um dos fundadores de Lampião da Esquina, jornal de resistência na cena gay brasileira da década de 1970, compara o ritmo do poema com o ritmo dos corpos de dois homens na cama:

O ritmo

O ritmo para ao meio, quer se entregar

mas muda o tema.

O cérebro domina a emoção.

O racional, o porquê domina.

Isso não é nunca a poesia. A poesia é a poesia.

Só pode parecer à entrega, a um coito.

Quando os pelos-verso se tocam há uma descarga elétrica.

Depois os corpos-poemas, rijos e gementes

realizam o processo.

E se abrem os lábios e os lábios.

O pênis-lápis, animalzinho dócil, que tanto acariciamos,

incha, e cresce mais.

Vai explodia o mundo, se puder.

A boca-palavra segue o jogo impronunciável,

os dentes querem ser punhais.

O insaciável pau busca agora o cu-inspiração, que desabrocha.

\footnotetext{
${ }^{8}$ Como se trata de textos de autoria diversa, o nome do poeta virá no corpo do parágrafo enquanto a referência trará os nomes das organizadoras.
} 
A cama-papel tem todos os perfumes dos corpos.

O pênis brinca a sério de forçar o umbigo mistério.

É um jogo, deus está em jogo.

Corpos que murmuram, suam, choram, sangra. Dor?

É o ritmo. Esse ritmo é o poema sendo fornicado.

Entre milhões de tentativas uma foda é divina,

igual ao nascimento de um poema (Machado e Moura, 2017, p. 97)

A duplicidade com que é construído o poema se concretiza, sobretudo, nas palavras compostas cujos radicais são oriundos tanto do corpo gay quanto do universo do poema. Assim, pelos-verso, corpos-poemas, pênis-lápis, boca-palavra, cu-inspiração e cama-papel são composições-chave a serviço de duas leituras possíveis: o ato de compor um poema, e o ato sexual entre dois homens. Pode-se perceber uma perspectiva que se assemelha ao conteúdo de certos poemas parnasianos, na obsessiva tarefa de mostrar o fazer poético; ao mesmo tempo, o poema quer fazer da relação homoafetiva uma experiência poética. Ambos, poesia e foda são ações demiúrgicas, um jogo sagrado. Mas se na poesia, sobretudo na perspectiva oitocentista, a inspiração era reportada às coisas do alto, às figuras míticas e sagradas, no poema-foda a inspiração vem de baixo, uma vez que é o cu o objeto de desejo do poeta. No fim das contas, o ritmo "é o próprio poema sendo fornicado".

O longo poema "Êxtase", de Horácio Costa, encena a prática do fisting, prazer que consiste em penetrar o ânus com o punho. Composto de opinião sobre a prática e descrição de como o poeta foi nela "introduzido", o poema aborda a parte do corpo que sempre esteve a serviço do prazer, mas sobre si recaiu uma maldição a ponto de ser objeto de uma verdadeira obsessão pelo seu aniquilamento como fonte e meta do prazer.

Êxtase

Apenas pelo lado da História

$O$ fisting é maldito.

Para muitos, este é o lado

mais importante.

Como um macho poderia

Explorar com consentimento

O cu de outro macho?

O fisting lembra Dracul

Palavra que contém "cul",

Vocábulo que não faz parte

Do famoso e influentíssimo

Dictionaire des Symboles

De Chavalier e Gheerbrant,

Onde se trata de tudo:

De Quimera, Crisma e Cristo;

De cu, pois, não.

O interdito da História

Pesa muito: é teleológico,

teológico, moral,

social, psicológico.

Assim começa a explicar-se

Por que apenas por esse lado

É maldito o cu. A sombra

Do impalador impõe-se (Machado e Moura, 2017, p. 131-132) 
É sobre a experiência do prazer propiciado pelo fisting que o poeta reflete. Nesse excerto do poema, o poeta apresenta como maldito o fisting porque o $\mathrm{cu}$, historicamente, foi interditado em todas as ambiências de poder e saber: da teologia à psicologia. Ou seja, o cu não pode ter história e tampouco simbolizar algo. O fist-fucking, nos diz Preciado (2014), é o exemplo concreto da tecnologia contrassexual, entendida como uma tecnologia política. Nessa prática, o pênis perde a majestade, é humilhado ao ser substituído por dedos, dildos e punho. E o objeto do prazer, com todo seu maldito esplendor, passa a ser o $\mathrm{cu}$, que assume a centralidade de um trabalho de desconstrução contrassexual justamente por abalar o sistema político e econômico heterocentrado: ${ }^{9}$

O trabalho do ânus não é destinado à reprodução nem está baseado numa relação romântica. Ele gera benefícios que não podem ser medidos dentro de uma economia heterocentrada. Pelo ânus, o sistema tradicional da representação sexo/gênero vai à merda (Preciado, 2014, p. 32).

O poema de Horácio Costa coloca em questão um problema próprio do Brasil, uma excolônia, cuja construção social e sexual se deu a partir de um estado falocrático e uma mentalidade patriarcal. É o país do pau gigante. Nesse ponto, o poema assume um tom de sarcasmo ao propor a subversão que o fisting produz numa cultura que elogia e glorifica o pau, ou melhor, tudo o que ele representa numa cultura patriarcal e sexista:

Eu não sabia que existia o fisting

Neste penetrante/penetrável continente

Do Brasil. Aqui, imperava o pênis

Com as suas regras, fantasmagorias.

Eduardo me garante, sem sabê-lo

Nem dizê-lo, que mudou o país

E eu com ele. Na terra do pau gigante,

Agora também há o fisting.

Este poema é um raciocínio

Sobre o meu país e o meu corpo:

Que mais haverá a pedir-se

A um punhado de versos?

Pois, o punho. Acolhe-o

O poema, generosamente,

Por que não estaria o cu

No dicionário de símbolos

Do cu na História a práticas

Do fisting. Não é só sexo

Como não apenas sexo é

$\mathrm{O}$ sexo entre cônjuges.

Corpo e história se entrelaçam.

$\mathrm{O}$ binômio cu e punho não era um ator

E hoje é. Neste exato momento há

Gente sendo fistada em São Paulo (Machado e Moura, 2017, p. 133-137)

O poema "Êxtase" pode ser lido como um manifesto contrassexual, segundo a proposta de Preciado. Há nele um forte tom de deboche na reflexão sobre o sistema político-social da sociedade brasileira, herdeira do pênis colonizador; além disso, ao assegurar que não se trata

\footnotetext{
${ }^{9}$ Para Preciado (2015), a heterossexualidade não se restringe ao modo como homens e mulheres desejam, mas constitui um sistema que acabou por moldar os sujeitos nos mais diferentes aspectos de suas vidas, seja no privado, seja no público. A economia, a religião e a política seguem as regras desse sistema.
} 
apenas de sexo, tanto o fisting quanto as relações heteronormativas dizem muito do modo como a história revela ou esconde o corpo e suas partes constituintes do desejo. Apresentar o cu e o punho como atores na contemporaneidade atesta, por um lado, o caráter contrassexual, e por outro, a noção clara de que tanto o ato sexual quanto o modo como interpretamos as identidades de gênero (ou as negamos) não passam de performances que não se cansam de serem repetidas e reinventadas.

$\mathrm{O}$ protagonismo do $\mathrm{cu}$, ator maldito de uma história de interditos e transgressões, é celebrado num poema de Roberto Piva, composto a partir de definições para essa parte do corpo que, mesmo alvo do desprezo de uns, torna-se fonte de curiosidade para outros:

Poema elétrico do cu

músculo de veludo na boca de todos os feirantes torpedeiros meninas de internato negociantes padeiros farofeiros torcidas exércitos de humanocultura onde você habita alucinante como promessa derradeira

$\mathrm{cu}$ boquiaberta entrada franca dos demônios pesadelo dos adolescentes fogueira da solteirona em férias árvore genealógica da Cloaca Mater onde foi chocado o ovo humano numa temperatura de 300 sóis

$\mathrm{cu}$ fonte de energia kundalini hóstia dos grandes libertinos fornalha dos cocainômanos boca azulada da verdade corpórea diagramada no infinito do desejo cu grande iniciador de tempestades amorosas vertigem verdadeira onde os amantes deslizam

$\mathrm{cu}$ vaporizador da Idade Média do corpo onda bioenergética de metais coloridos omoplatas carregadas de hidrogênio leopardos alucinados de tanto veludo

$\mathrm{cu}$ de cabelos negros loiros ruivos castanhos cipoalde [sic] intrigas onde o caralho se perde se desnorteia desmaia de gozo na contração do espasmo da alegria erótica

cu selvagem assaltante noturno diurno trombadinha espadachim das estradas que levam ao Grande Precipício anunciador de Paixões

$\mathrm{cu}$ de penugens suaves \& sumarentas flor carnívora labareda policiada pela civilização ave louca solitária perdida bêbada amorosa cu proletário do corpo grande escorpião revoltado teu voo de liberdade começa a acontecer (Machado e Moura, 2017, p. 232-233)

O título e a estrutura do texto, composto de enumerações, lembram o poema "Eu canto o corpo elétrico", de Walt Whitman, em Folha de relva. Entretanto, se naquele poema é o corpo quem recebe uma infinidade de designações, neste, a lista recai sobre o cu. Objeto de apreciação e depreciação, o cu merece ser historicizado, e é o que Piva faz poeticamente nas definições que demonstram a relação da humanidade com a parte do corpo que, não apenas é responsável por expelir o excremento, mas também se torna o vocábulo para denominar o abjeto.

O poema de Piva, assim como Preciado (2015), apresenta o cu como proletário, uma vez que, não servindo como objeto romântico nem reprodutor, trabalha exclusivamente para o desejo. 
Além disso, como não se filia ao sexo ou ao gênero, o cu é um órgão sexual não binário, não é masculino nem feminino. Por isso, em nenhum momento o poema territorializa os domínios do cu como objeto de prazer. Se ele não é propriedade privada do sistema hetereocentrado, tampouco será dos sujeitos desviantes. Preciado (2015, p. 36) aponta para a urgência de se "ressexualizar o ânus (uma zona do corpo excluída das práticas heterocentradas, considerada como a mais suja e a mais abjeta) como centro contrassexual universal".

Diferente de Preciado, para quem o cu é o centro de uma filosofia e modo de vida contrassexual, Javier Saez e Sejo Carrascosa (2016), na arqueologia dos discursos sociais e culturais sobre o cu, argumentam que, na tradição heterocentrada, a sexualidade anal está eivada de uma dicotomia hierarquizante:

Ser ativo ou passivo historicamente a uma relação de poder binário: dominador-dominado, amo-escravo, ganhador-perdedor, forte-fraco, poderoso-submisso, proprietário-propriedade, sujeito-objeto, penetrador-penetrado, isso tudo dentro de outro esquema subjacente de gênero: masculino-feminino, homem-mulher (Saez e Carrascosa, 2016, p. 30).

De qualquer modo, tanto o poema de Horácio Costa quanto o de Roberto Piva colocam em discussão as fantasmagorias do $\mathrm{cu}$, independentemente do sistema heterocentrado ou contrassexual. O cu é queer, um objeto abjeto, mas desejado justamente por ser o que é, um paradoxo. Talvez, a maldição que recai sobre o cu através da história da humanidade só pode mesmo ser desconstruída na base da ironia, do sarcasmo e do humor, qualidades que a paródia imprime tanto ao texto de Piva quanto a abordagem teórica de Preciado e de Saez e Carrascosa. Também é o que ocorre aos poemas do poeta Waldo Motta, que trabalha com a categoria do profanatório na sua poética erótica, ilustrada na antologia com este poema:

Encantamento

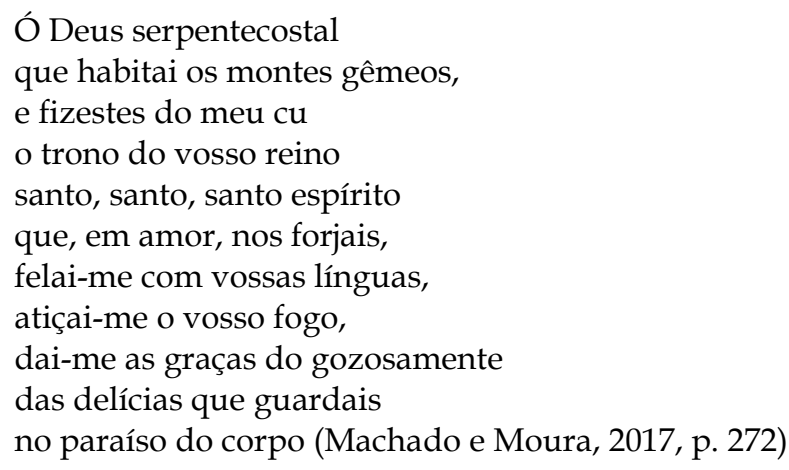

Como se vê, nem sempre o desejo é performado de modo bem comportado. Aliás, a poética queer espelha a face contestadora e transgressiva dos sujeitos LGBTQ, quase sempre se apropriando da sátira, da paródia, do riso debochado e profanatório. Exemplos de poesia fescenina na temática gay povoam a coletânea, desde Laurindo Rabelo, um Bocage brasileiro, que poetizava sobre fanchonos numa linguagem desbocada, ou uma Hilda Hilst, com sua trupe de seres LGBTQ saídos dos contos de fada (o reizinho gay, o anão bissexual, a fadinha lésbica), até Glauco Mattoso, poeta gay cego que trata dos tabus da sexualidade sem nenhum compromisso com moralismos. Completa esse rol o poeta Waldo Motta, com seu riso carnavalizado a rebaixar as moralidades de uma tradição cristã. $O$ poema de Motta parodia uma oração, mas todos os elementos do sagrado cujas crenças e teologias topografam no alto, sobre a cabeça da humanidade, aqui são rebaixados. A morada do deus "serpentecostal" (o pênis) é o cu. Trata-se, portanto, da oração de um gay ao seu objeto de adoração. Como o poema de Motta, a antologia apresenta outros com a característica transgressora em relação às coisas e personagens sagrados. Nesse caso, na profanação ou na carnavalização do sagrado, manifestase a intenção de horizontalizar a relação sagrado-profano.

Por que a obsessão pelo cu nesses poemas? Por que é preciso usar uma poética mal comportada ao falar do desejo e dos prazeres dos sujeitos minoritários? Ora, organizar uma antologia que resgate na literatura a homocultura não é simplesmente trazer à luz da crítica 
literária mais um dos tantos temas que podem ser garimpados na historiografia literária. Tratase de uma ação política de fazer o cânone falar o que silenciara, de mostrar o que estava sempre ali, mas não evidenciado. ${ }^{10}$

Essa tomada de posicionamento diante da literatura exemplifica o que Paco Vidarte (2019) define como "ética bixa". Para o autor, os sujeitos LGBTQ têm usado modelos e abordagens heteronormativas como referenciais de valores, de condutas morais e de pensamento. Num texto corrosivo de ironia, sem deixar de ser uma potência reflexiva, Vidarte (2019, p. 30) afirma que "no fim das contas, diriam os psicanalistas, toda ética é anal, oral ou fálica. Uma ética bixa deverá, decididamente, ser anal: uma Analética, para dizer uma besteira".

A teoria da dissidência LGBTQ é toda construída de uma linguagem desviante, repleta de ironia e marcada por um viés debochado, mas sem deixar de lado a articulação de um pensamento crítico. Quem disse que uma teoria e uma crítica devam ser carrancudas? Esses sujeitos do discurso afrontam com uma linguagem escrachada, mas perfeitamente plausível em relação à natureza de desconstrução de verdades hegemônicas. O riso que imprime o deboche desses textos crítico-teóricos é proporcional à temática que abordam, e rechaçam os discursos acadêmicos acostumados ao pensamento heterocentrado. Para exemplificar o riso que não desqualifica o teórico, cito um trecho em que Vidarte defende a ética bixa:

O que o poder entende ser o cu de uma bixa não é o mesmo que uma bixa entende que é o seu cu. Para o poder somos paus no $\mathrm{cu}$, cus sem eu, sem possibilidade, necessidade ou atitude para ter qualquer iniciativa política. Cus para dar, cus para tomar. Cus que reclamam serviços públicos para não se cagarem pelas calçadas: está bem, vamos dar isso, não queremos que encham tudo de merda. Cus despolitizados. Pois bem, meu cu é coletivizado, que não é o mesmo que ser meu cu. Tenho um cu solidário, o que é diferente de ter um cu que busca seu prazer egoisticamente. Tenho um cu entregue, o que é diferente de ter um cu vampiro. Tenho um cu engajado, incapaz de foder com necas anônimas, de direita, depauperadas, imigrantes: dando na mesma para ele. Ou, ao menos, essa é a ética à qual aspira, sua analética (2019, p. 34-35).

Quem poderá acusar o trecho acima de uma linguagem chula e despolitizada, ou assegurar que não há aí pleno exercício de reflexão sobre o uso que fazemos dos nossos corpos, íntima e publicamente? A presença do cu como tema de uma poética e de uma teoria sobre práticas eróticas de sujeitos LGBTQ, portanto, se fere a leitura dos sujeitos não envolvidos e comprometidos com as causas minoritárias, já surtiu um efeito no instante mesmo em que produz um incômodo, porque tirou dos eixos uma leitura acostumada com comportamentos normatizados.

\section{Orelha, prefácio e posfácio: crítica que nasce com a obra}

Elementos paratextuais, a orelha, o prefácio e o posfácio não podem ser negligenciados numa pesquisa, pois compõem uma primeira análise crítica do conteúdo, além, é claro, de justificarem a motivação de quem editou o livro. No caso das antologias, esses elementos ganham ainda mais importância, já que expressam um mínimo de informação sobre a temática da coletânea. Chama a atenção o fato de que os sujeitos que prefaciam as coletâneas LGBTQ geralmente desempenham um papel de militância política ou artística em favor dos direitos dos sujeitos dissidentes.

Sendo o corpo político e também erótico, não se pode pensar que os discursos do desejo e do prazer encenados em antologias como a Poesia gay brasileira (2017) diminuem sua natureza política. Pelo contrário, apenas reforçam a necessidade de se ler o desejo dos corpos para além do compulsório. Nesse sentido, ao chamar a atenção para os poemas eróticos cujas vozes descrevem o

\footnotetext{
${ }^{10}$ No capítulo "Essas histórias do amor maldito", do livro Devassos no Paraíso (2018, p. 238-259), João Silvério Trevisan, um militante LGBTQ escritor (ou o contrário?), faz brevemente um passeio pela literatura brasileira para escavar vestígios de autorias homoafetivas. Tirar esses textos do armário, lê-los a partir de uma nova perspectiva, retirar o véu da acostumada leitura heteronormativa, pode ser uma atitude política frente a literatura que construímos.
} 
que lhes afeta enquanto sujeito do desejo, acredito acentuar o caráter político de Eros. Não se trata, portanto, de pensar o erotismo como uma representação do prazer do corpo apolítico.

$\mathrm{Na}$ apresentação da antologia gay, as organizadoras Amanda Machado e Marina Moura confirmam a potência política de sua coletânea em tempos de boicote às artes e ao erótico e provocam: "Porque para nós, se amor é doença, só podemos pensar aqui em uma 'Pathologia de Eros'" (2017, p. 20). Além disso, advogam em torno da urgência de se dar nome às coisas, da necessidade de que a literatura se assuma também pelo conteúdo que veicula e pela autoridade que a engendra:

Poesia gay brasileira, Poesia LGBT brasileira, ou mesmo Poesia LGBTQIA+ brasileira. Como esta compilação vai se chamar? Sem entrar na perigosa discussão do que poderia ser entendido como construção ou categorização de um gênero literário, escolhemos "Poesia gay brasileira" por acharmos que o título estabelece comunicação direta com leitores que se interessam pelo tema e pela poesia (2017, p. 22-23).

Natalia Borges Polesso, vencedora do prêmio Jabuti com seu Amora, (2016), e Jean Wyllys, militante LGBT e ex-deputado federal, assinam, respectivamente, orelha e prefácio da obra, partindo do problema de titulação da coletânea, ou seja, do que objetivamente constituiria uma poesia gay: a sexualidade dos autores ou a temática? Enquanto Jean Wyllys afirma que rotular uma poesia de gay "é só a forma de dizer que aqui se reuniu um conjunto de poemas que não ignorou os modos de vida da comunidade de gays, lésbicas, bissexuais, travestis e transexuais" (2017, p. 8), Polesso assegura que o livro "é também uma antologia lésbica, bi, queer, trans" e o indica a "todo o amante que não veio, para as desconhecidas que acenam de longe, para amélias angelicais, as discípulas de Safo, as safadas, os velhos, a moça, aquelas que atravessam a rua, travestidas, as mal educadas as polidas".

Certamente é um tema polêmico, mas uma mirada nos poetas selecionados indica que as organizadoras da antologia Poesia gay brasileira (2017) partiram da temática e não necessariamente da identidade sexual de seus autores. Nesse sentido, não deve causar estranhamento que poetas héteros estejam entre autores assumidamente gays e lésbicas. De igual modo, se a poesia erótica de temática gay atual envolve uma complexidade de modos de pensar a sexualidade e suas políticas, sabe-se que, até a primeira metade do século XIX, a presença do gay e da lésbica na literatura brasileira tinha, com alguma exceção, uma dupla função: depreciar desafetos a partir dos qualificativos pejorativos (viado, bicha, maricas, sapatão etc.) ou ilustrar, pela literatura, os estudos da psicologia, segundo a qual, toda sexualidade que não era heteronormativa estaria na lógica do desvio e da perversão.

As organizadoras têm clareza quanto às diferentes abordagens sobre a homossexualidade por meio do painel de poetas escolhidos (gays ou héteros), e escolheram o formato antologia justamente "por acreditar que ele permite que habitem, em espaço único, multiplicidade de temas (homoafeto, homoerótico, preconceito etc.), de tempos (poetas de 1826 até hoje) e de espaço (poetas do Norte ao Sul do país)" (Machado e Moura, 2017, p. 24). Uma antologia sobre a homossexualidade, portanto, acaba por refletir o olhar da sociedade e da própria literatura através dos tempos. Entretanto, cabe lembrar que a saída do armário de poetas e prosadores era também um tabu dentro do próprio território da literatura. ${ }^{11}$

Um panorama ousado, que fez um recorte (toda antologia é recorte) considerando espaçotempo-temática, não deixa de demarcar uma posição de leitura do cânone que se desloca dos temas privilegiados (a periodização da poesia e as escolas literárias) para a temática da sexualidade não normativa. A justificativa das organizadoras sugere que não devemos esperar de uma antologia como essa uma postura que flerta com o politicamente correto, pelo contrário, reunir diferentes olhares sobre a homossexualidade é uma forma de situar temporal e culturalmente a questão da homossexualidade, de modo a se deixar em aberto o problema do olhar da própria literatura sobre esses sujeitos através do tempo: a homossexualidade como foi motivo de escárnio, xingamento e rebaixamento do outro, considerada um desvio moral e maldita.

\footnotetext{
${ }^{11}$ Sobre esse tabu, sugiro o depoimento do professor e poeta Horácio Costa ao canal no Youtube criado pelas organizadoras da antologia gay para divulgar a obra e disponível em: https://www.youtube.com/watch?v=RvjKBnwkcx4.
} 


\section{Sobre desterritorializar o desejo na cena literária}

Por que falar do homoerotismo, quando se sabe que a homofobia, a lesbofobia e a transfobia matam? Por que se deter nos prazeres do corpo dissidente quando as estatísticas comprovam que o Brasil é um dos países que mais matam LGBTQ? Como um território de disputas, frequentemente garantido a discursos hegemônicos, a literatura tem sido tensionada a mostrar rostos, vozes e corpos de sujeitos invisibilizados. Reconhecendo-se a presença do erotismo quase como um gênero literário desde a Antiguidade Clássica, cabe agora repensar o papel do erótico para quem, por serem corpos eróticos que fogem ao paradigma do erótico clássico, quando apareciam na literatura, representavam justamente o desvio.

Audre Lorde, poeta negra e lésbica estadunidense, em Sister outsider (2007), cuja primeira edição é de 1984, num texto intitulado "Uses of the erotic: the erotic as power", sai em defesa do erótico ao afirmar que as mulheres foram ensinadas a colocar sob suspeição o poder do erótico e, assim, desistir da descoberta da essência do desejo. Segundo Lorde, ao serem educadas para recusar esse poder, as mulheres deixaram o erotismo sob a tutela do masculino, que, então, passou a decidir sobre a linguagem e as imagens que podem ou não servir ao seu prazer: "somos ensinadas a separar a demanda erótica das áreas mais vitais de nossas vidas, exceto o sexo. E a falta de preocupação com a raiz erótica e as satisfações de nosso trabalho é percebida em nosso descontentamento em muito do que fazemos" (Lorde, 2007, p. 55, tradução nossa).

Lorde coloca em xeque o erotismo a serviço de demandas do masculino. Daí que a ele se vinculem sexismo, abusos, crimes sexuais, feminicídios e tantas outras mazelas próprias das masculinidades tóxicas. É preciso, portanto, reaver o erótico das mãos do masculino e tratá-lo como uma pulsão vital do humano. Tanto quanto as mulheres empoderadas, gays, lésbicas, bi, travestis e transexuais são sujeitos perigosos, que amedrontam as masculinidades viris, essas sim, frágeis e instáveis.

Tanto as vozes da literatura quanto da crítica literária atual parecem reivindicar um conhecimento de causa, uma autoridade que não se desvincula de uma identidade sexual e de gênero. O autor e o crítico se dizem corpos desejantes. $\mathrm{O}$ desejo e o prazer performados nesses poemas falam sobre a diversidade sexual, provocam o leitor, vociferam contra o sistema, denunciam uma visão heterocentrada da sexualidade, procuram erodir discursos hegemônicos e compulsórios, advogam em causa própria, desautorizam as interdições, demolem os simulacros erigidos para mimetizar uma verdade sobre sexualidade e identidade. Retomando o que Suely Rolnik discute como micropolítica ativa e ética, a representação da sexualidade nas artes pode ser uma forma desterritorializar o desejo, porque são atos criativos, ou seja, "as ações do desejo consistem portanto em ato s de criação que se inscrevem nos territórios existenciais estabelecidos e suas respectivas cartografias, rompendo a cena pacata do instituído" (Rolnik, 2018, p. 51).

Essa ruptura ocorre numa hora em que a cultura de um modo geral vem sendo achincalhada por ações governamentais contra a diversidade estética, sexual e política. Em momentos de tensão é que as artes precisam se colocar na frente do campo de negociação. Como tantas antologias em prosa e verso que têm coligido textos em torno da temática LGBTQ, a antologia Poesia gay brasileira (2017) pode ser compreendida com um rasgo inabitual na fita de Moebius da literatura brasileira. Mas essa fita precisa continuar a ser cindida.

\section{Referências}

BUTLER, Judith (2017). Problemas de gênero: feminismo e subversão de identidade. Tradução de Renato Aguiar. Rio de Janeiro: Civilização Brasileira.

BUTLER, Judith (2018). Corpos em aliança e a politica das ruas: notas para uma teoria performativa de assembleia. Tradução de Fernanda Siqueira Miguens. Rio de Janeiro: Civilização Brasileira. 
BUTLER, Judith (2019a). Atos performáticos e a formação dos gêneros: um ensaio sobre a fenomenologia e teoria feminista. In: HOLLANDA, Heloísa Buarque de (Org.). Pensamento feminista: conceitos fundamentais. Rio de Janeiro: Bazar do Tempo. p. 213-230.

BUTLER, Judith (2019b). Corpos que importam: os limites discursivos do "sexo". Tradução de Veronica Daminelli e Daniel Yago Fraçoli. São Paulo: n-1; Crocodilo.

FOUCAULT, Michel (2015). História da sexualidade 1: a vontade de saber. Tradução de Maria Thereza da Costa Albuquerque e J. A. Guilhon Albuquerque. São Paulo: Paz e Terra.

LORDE, Audre (2007). Uses of the erotic: the erotic as power. New York: Crossing Press. (Sister Outsider)

LOPES, Denilson (2002). Uma história brasileira. In: LOPES, Denilson. O homem que amava rapazes e outros ensaios. Rio de Janeiro: Aeroplano. p. 121-164.

MACHADO, Amanda; MOURA, Marina (Org.) (2017). Poesia gay brasileira: antologia. Belo Horizonte: Machado; São Paulo: Amarelo Grão.

PAZ, Octavio (1994). A dupla chama: amor e erotismo. Tradução de Wladir Dupont. São Paulo: Siciliano.

PRECIADO, Beatriz (2011). Multidões queer: notas para uma política dos "anormais". Estudos Feministas, Florianópolis, v. 19, n. 1, p. 11-20, jan./abr.

PRECIADO, Beatriz (2014). Manifesto contrassexual: práticas subversivas de identidade sexual. Tradução de Maria Paula Gurgel Ribeiro. São Paulo: n-1.

ROLNIK, Suely (2018). Esferas da insurreição: notas para uma vida não cafetinada. São Paulo: n-1.

RUBIN, Gayle (2017). Políticas do sexo. Tradução de Jamille Pinheiro Dias. São Paulo: Ubu.

SAEZ, Javier; CARRASCOSA, Sejo (2016). Pelo cu: políticas anais. Tradução de Rafael Leopoldo. Belo Horizonte, MG: Letramento.

TREVISAN, João Silvério (2018). Devassos no paraíso: a homossexualidade no Brasil, da colônia à atualidade. Rio de Janeiro: Objetiva.

VIDARTE, Paco (2019). Ética bixa: proclamações libertárias para uma militância LGBTQ. Tradução de Maria Selenir Nunes dos Santos e Pablo Cardellino Soto. São Paulo: n-1.

WITTIG, Monique (2006). El pensamiento heterosexual y otros ensayos. Tradução de Javier Sáez e Paco Vidarte. Madrid: Egales. 